\title{
Flowchart of Personal Injury Claims (PIC) in Loss of Earning
}

\author{
Najihan Awang @ Ali ${ }^{1^{*}}$, Nik Ruslawati Nik Mustapa ${ }^{2}$, Nurul Husna Jamian Syadatul Syaeda Mat \\ Saleh $^{3}$, Muhammad Azri Yahya ${ }^{4}$ \\ ${ }^{1}$ Faculty of Computer and Mathematical Sciences (FSKM), Universiti Teknologi MARA, Perak Branch, \\ Tapah Campus, 35400 Tapah Road, Perak, Malaysia \\ Corresponding author: *najihanali@uitm.edu.my \\ Received Date: 28 July 2018 \\ Accepted Date: 12 November 2018
}

\begin{abstract}
Road accidents are a major contribution in personal injury claims. The accident victims are allowed to claim a certain amount of damages from negligible parties. In Malaysia, courts adopt the traditional method of Multiplier-Multiplicand Approach to calculate the compensation amount. However, there is still no available tool to estimate personal injury claim with respect to loss of earning. This study aims to develop a flowchart for Personal Injury Claims (PIC) to calculate the compensation amount for loss of earning in Malaysia regarding the Ogden Table introduced by the United Kingdom. A flowchart is proposed and built using Microsoft Visio. The users will fill up the details displayed to get the estimated compensation amount. It is expected that claimants, courts and lawyers would be among the target users. To get started, nine elements as inputs will fill up by users. Then, there is three important processes involved in order to calculate the damages for loss of earning. In a conclusion, at the end of the session, the users will know their entitled amount of claim in loss of earning.
\end{abstract}

Keywords: Road accidents, claims, loss of earning, a flowchart

\section{INTRODUCTION}

Road accidents involving various types of vehicles increases almost every day. The statistics were recorded 400,788 road accidents nationwide between January and September last year (Bernama 2017). While, The Malaysian Institute of Road Safety Research (MIROS) reported that there are 521,466 cases of road traffic accidents recorded in 2016 as compared to 489,606 cases in 2015 . The increase of $6.5 \%$ showed the rise in personal injury claims by an injured party because of the other's negligence. As the aggrieving party, they are allowed to claim a reasonable amount of damages as a result of the road accidents.

Massita et al. (2012) and Lim (1995) defined compensation as an award of the amount given to the wrong party who had pleaded responsible for the offences committed and requires a certain amount of payment to victims or beneficiary's parties. As to the compensation or damages, the entire vehicle owners registered to third-party insurance cover special damages and general damages. Currently, Malaysia courts use The Traditional Multiplier-multiplicand Approach to calculate the compensation amount in loss of earning.

The compensation amount using the Multiplier-Multiplicand approach is as follows:

Sum Award = Multiplicand $*$ Multiplier

where:

Multiplicand $=$ Loss of Earning $=$ Pre Injury Earning - Post Injury Earning

Multiplier $=$ Pre-accident Earning - Post Accident Earning

$=$ if the claimant's age 30 and below $=16$ 
$=$ if the claimant's age 31 and $54=(55-$ age at injury or death date $) / 2$

Comments for this traditional approach: It is logically not reasonable to let the loss of future earning calculated by only multiplying the loss of earning with how many years left until the retirement age. The accuracy of the multiplier has been disputed since the latest age for retirement increases to 60 years old. While the government has implemented a new retirement age, there is no corresponding change is made to the Civil Law Act 1956. This showed the weakness of the traditional calculation method assessing the loss of earning in personal injury claims.

\section{LITERATURE REVIEW}

Several studies (Massita et al 2012; Haslifah et al. (2011) suggested the Ogden Table where a series of actuarial tables are applied. This is the practice in the United Kingdom as shown in Table 1:

Table 1: The development of Ogden table in the United Kingdom

\begin{tabular}{|c|l|}
\hline Year & \multicolumn{1}{c|}{ Development } \\
\hline 1984 & $\begin{array}{l}\text { The 1st actuarial table was published for personal injury and fatal accident claims by the } \\
\text { Government Actuary's Department (indicated by mortality rate) }\end{array}$ \\
\hline 1994 & $\begin{array}{l}\text { The } 2^{\text {nd }} \text { edition of the table was published considering contingencies other than the } \\
\text { mortality rate }\end{array}$ \\
\hline 1998 & $\begin{array}{l}\text { The United Kingdom implemented the new English Life Table and the committee reflected } \\
\text { the changes as the } 3^{\text {rd }} \text { edition }\end{array}$ \\
\hline 2000 & $\begin{array}{l}\text { Improvement of the edition by including explanatory notes for the tables to ease the } \\
\text { lawyer, judges and juries }\end{array}$ \\
\hline 2004 & $\begin{array}{l}\text { The tables were updated twice by encountering the life expectancy factor and due to the } \\
\text { latest version of English Life Table data }\end{array}$ \\
\hline 2011 & $\begin{array}{l}\text { The } 6^{\text {th }} \text { edition was published to cover the new data for contingencies other than mortality, } \\
\text { such as educational level, the likelihood of employment, disability and economic activity }\end{array}$ \\
\hline $\begin{array}{l}\text { The } 7^{\text {th }} \text { edition is the latest edition due to mortality rates used underlying the latest national } \\
\text { population projections. This edition also provides the rate of interest from }-2.0 \% \text { to } 3.0 \% \\
\text { (rising in steps of 0.5\%) }\end{array}$ \\
\hline 2017 & $\begin{array}{l}\text { Improvement in discount rate since the } 7^{\text {th }} \text { edition is not tabulated at a discount rate- } \\
0.75 \% \text {. Thus, the addition of a column of multipliers in each table calculated at a rate } \\
\text { return of }-0.75 \% \text {. }\end{array}$ \\
\hline
\end{tabular}

Table 1 showed the development of Ogden Table in the United Kingdom in response to the global economy and human livelihood. The practice in the United Kingdom can provide a useful lesson to Malaysia in order to minimise the waiting process and duration in getting the compensation claims. At the moment, Malaysia is still using Multiplier-Multiplicand Approach for calculating the compensation amount in loss of earning in Malaysia. As the approach largely relies on a manual system, this may possibly lead to problems like a miscalculation, time delay and cost ineffective.

In order to address these problems, this study adopts the Ogden Table as a model to suggest an improved method for the calculation of personal injury claims. There is also no integrated tool for that purpose in Malaysia as widely deployed in developed countries such as the United

Objectives of this research:

1. To develop a flowchart for the loss of earning in personal injury claims system.

2. To build a prototype tool in predicting the compensation amount on the loss of earning in Malaysia. 


\section{CONCEPT OF FLOWCHART}

In order to create a system, the first step is to design an algorithm such as a flowchart. According to Gaddis (2008), a flowchart is a diagram that graphically depicts the steps that take place in a system that consists of four types of symbols which are ovals, parallelograms, rectangles and diamonds. Each of these symbols represents a step in the system. The symbols are connected by arrows that indicate the flow of the program. To step through the symbols in the proper order, begin at the start terminal and follow the arrows until reach the end terminal.

\section{FLOWCHART FOR PIC}

A flowchart is proposed and built using Microsoft Visio. Figure 1 show the flowchart proposed that follow the guidelines applied in Ogden Table which is verified by Actuaries in United Kingdom. Thus, our research try comes out with this idea to implement in Malaysia market.

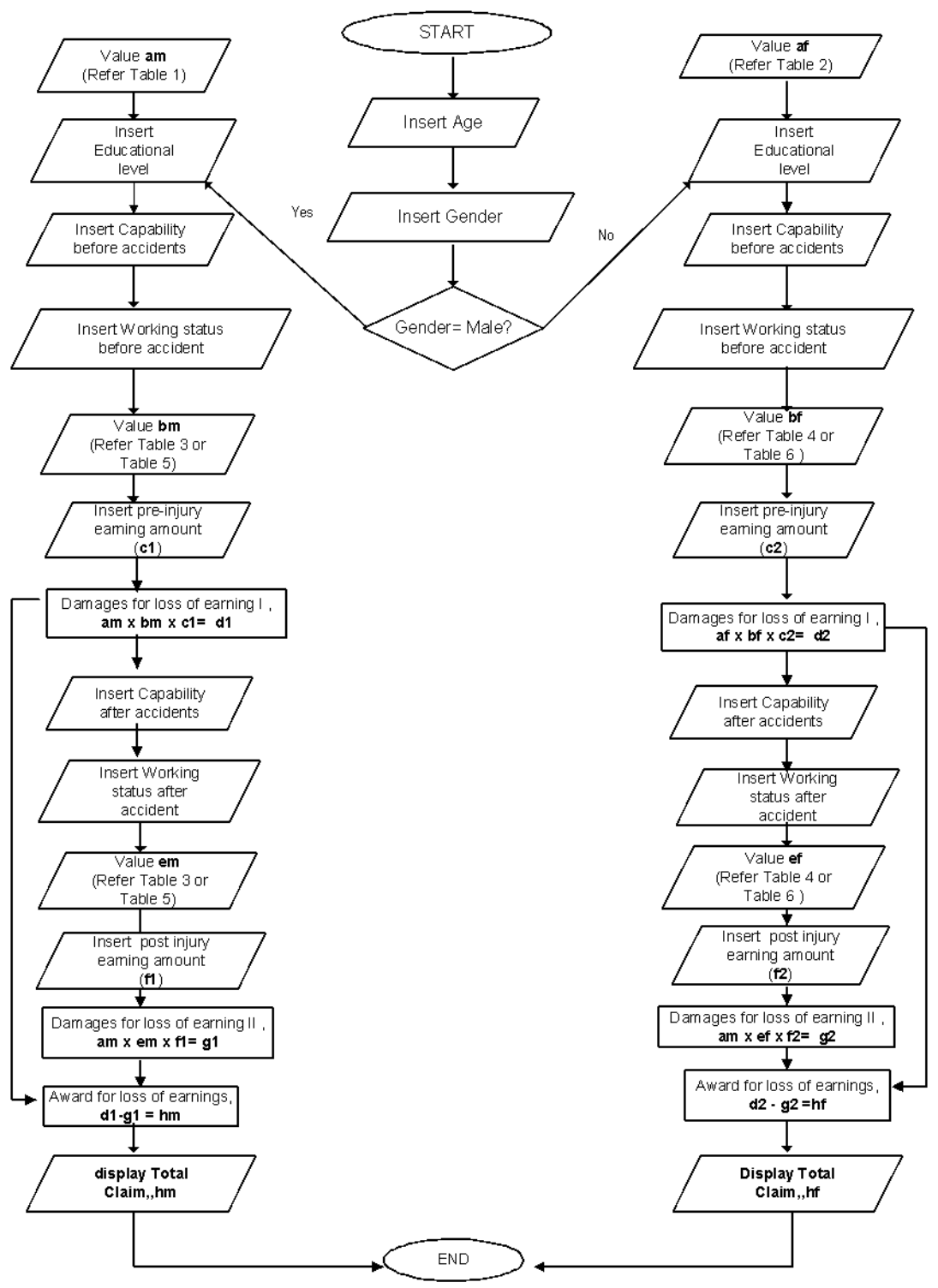

Figure 1: Flowchart for Personal Injury Claims Calculator (PICC) 
Table 2 explain each step occur in the flowchart for PIC. The flowchart basically facilitates the target users (the claimants, lawyer and the court) and will facilitate the calculation of injury claim which would serve justice and accuracy of personal injury in road accidents.

Table 2: Explanation of Flow Chart for PICC

\begin{tabular}{|c|c|}
\hline Step & Description \\
\hline 1) Beginning (start) & User key in details of their age and gender \\
\hline $\begin{array}{l}\text { 2) Gender: } \\
\text { male will used am } \\
\text { female will used af }\end{array}$ & $\begin{array}{l}\text { am }=\text { multiplier value of loss of earning to pension age until } 65 \\
\text { males with basis } 21 / 2 \% \text { rate of return (refer to Table } 9 \text { Ogden } \\
\text { Table). Let assume as Table } 1 . \\
\text { af= multiplier value for loss of earning to pension age } 60 \text { females } \\
\text { with basis } 21 / 2 \% \text { rate of return (refer to Table } 8 \text { Ogden Table). Let } \\
\text { assume as Table } 2 \text {. }\end{array}$ \\
\hline $\begin{array}{l}\text { 3) The user insert their } \\
\text { educational level, capability } \\
\text { before accidents and the working } \\
\text { status before the accident (pre- } \\
\text { injury) }\end{array}$ & $\begin{array}{l}\text { The system will identify their information and used notation: } \\
\text { bm= multiplier for male by considering able to work before } \\
\text { accident with their educational level and working status (Refer } \\
\text { Table A Ogden Table) .Let assume as Table } 3 \text {. If disabled to work } \\
\text { before accident, (Refer Table B Ogden Table) .Let assume as } \\
\text { Table } 5 \text {. } \\
\text { bf = multiplier for female by considering able to work before } \\
\text { accident with their educational level and working status (Refer } \\
\text { Table C Ogden Table) .Let assume as Table } 4 \text {. } \\
\text { If disabled to work before accident, (Refer Table D Ogden Table) } \\
\text {.Let assume as Table } 6 \text {. }\end{array}$ \\
\hline $\begin{array}{l}\text { 4) The user insert their earning } \\
\text { of pre-injury }\end{array}$ & $\begin{array}{l}\mathbf{c 1}=\text { for male } \\
\mathbf{c 2}=\text { for female }\end{array}$ \\
\hline $\begin{array}{l}\text { 5) First process } \\
\text { Damages for loss of earning I }\end{array}$ & $\begin{array}{ll}\text { Male: } & \mathbf{d} 1=\mathbf{a m} \times \mathbf{b m} \times \mathbf{c 1} \\
\text { Female : } & \mathbf{d} \mathbf{2}=\text { af } \times \text { bf } \times \mathbf{c} 2\end{array}$ \\
\hline $\begin{array}{l}\text { 6) The user insert working status } \\
\text { and capability after accidents } \\
\text { (post-injury) }\end{array}$ & $\begin{array}{l}\text { em }=\text { for male (the value of multiplier refer to Table } 3 \text { or } 5 \text { ) } \\
\text { ef }=\text { for female (the value of multiplier refer to Table } 4 \text { or } 6 \text { ) }\end{array}$ \\
\hline $\begin{array}{l}\text { 7) The user insert their earning } \\
\text { of post-injury (provided in the } \\
\text { report of court cases) }\end{array}$ & $\begin{array}{l}\mathbf{f 1}=\text { for male } \\
\mathbf{f 2}=\text { for female }\end{array}$ \\
\hline $\begin{array}{l}\text { 8) Second process } \\
\text { Damages for loss of earning II }\end{array}$ & $\begin{array}{l}\mathrm{g} 1=\mathrm{am} \times \mathrm{em} \times \mathrm{f1} \\
\mathrm{g} 2=\text { af } \times \text { ef } \times \mathrm{f} 2\end{array}$ \\
\hline $\begin{array}{l}\text { 9) Third process } \\
\text { Total claim }\end{array}$ & $\begin{array}{l}\mathbf{h m}=\mathrm{d} 1 \mathrm{-g} 1 \\
\mathbf{h f}=\mathrm{d} 2-\mathrm{g} 2\end{array}$ \\
\hline
\end{tabular}

\section{CONCLUSION AND RECOMMENDATION}

In this paper, we have developed a flowchart to calculate the loss of earning in personal injury claims. As Malaysia still relies on a manual system based on the Multiplier-Multiplicand Approach which is timeconsuming and cost ineffective, this study is significant to increase the quality of the compensation amount of loss of earning in Malaysia. The Ogden Table is a feasible method to follow as employed in this study. We add value to the method by flowchart to facilitate the courts, claimants and lawyers in the assessment of the compensation. To provide more efficient and accurate calculation system, we recommend future research to consider part or region of claimant's injury, their contingency, retirement age of above 60 years (especially for those 70 years and above). 


\section{REFERENCES}

Bernama (2017), retrieved on 26 June 2018 at https://www.nst.com.my/news/nation/2017/11/302157/5083-road-accident-deaths-recorded-jan-sept2017.

Gaddis,T. (2008). Starting Out with Programming Logic and Design. New York: Pearson International.

Haslifah,H., \& Massita, M (2011). Factors in Estimating Compensation in Personal Injury and Wrongful Death using Actuarial Approach Centre for Actuarial Studies. Paper presented at the International Conference on Financial Management and Economics, http://www.ipedr.com/vol11/64-W10024.pdf )

Lim,H.S. (1995). Assessment of Damages in Personal Injury and Fatal Accident Claims: Principles and Practice. Perpustakaan Negara Malaysia, Kuala Lumpur: Marsden Law book Sdn Bhd.

Massita, M., Haslifah, H. \& Halim, K. (2012). The Traditional Multiplier-Multiplicand Approach. Paper presented at the International Conference on Economic, Business and Marketing Management. page 29. http://www.ipedr.com/vol29/59-CEBMM2012-R10013.pdf. 